\title{
Livestock Farm Networks, a system at the center of French farming development
}

\author{
Carole Jousseins $^{1 *}$ Jocelyn Fagon $^{1}$ Julien Belvèze ${ }^{1}$ \\ Gérard Servière ${ }^{2}$
}

\section{Keywords}

Farming system, rearing system, livestock management, knowledge organization system, agricultural development, advisory officer, sustainable agriculture, France

Accepted: 21 December 2014; Published: 25 March 2016
1. Institut de l'Elevage (French Livestock Institute), BP 42118, 31321 Castanet-Tolosan Cedex, France.

2. Institut de l'Elevage, 63170 Aubière, France.

* Corresponding author

Tel: +33 (0)5 617544 41; Email: carole.jousseins@idele.fr

\section{Summary}

The Livestock Farm Networks system is dedicated to the development of herbivore farming. As the Networks result from the history of French agricultural development, they are found throughout France and are organized at local level. The originality of the system lies in the partnerships between farmers, chambers of agriculture and the French Livestock Institute, and in that it uses a global approach to take into account the diversity of livestock farming regions and the study of livestock farming systems. The aim is not to be exhaustive, but to be representative of herbivore farming systems based on the selection of the studied systems. The aim is also to assess the evolution of these systems and to disseminate the benchmarks obtained from the monitoring of 1900 farms by 210 chamber-of-agriculture agents, guided by 35 project leaders from the French Livestock Institute, and financed and supported by public authorities and the professional agriculture bodies. The regional and national enhancement of the Networks are aimed at different audiences: farmers, advisers, teachers (for advice or training), individuals or collectives, and local and national decision makers to improve their understanding of livestock farming systems and to measure the impact of new farming policies and lead their implementation. We also show the capacity of the Networks to mobilize themselves on emerging themes. Sustainability, competitiveness, working conditions or even environmental issues have been covered by the study fields of the system, well before sustainable development became a central theme. The Networks as a partnership system are sometimes complex to manage and may appear costly, but the strong and well-recognized partnership has made them a valuable resource and ensures their recognition and legitimacy. The variety of farming productions and the heterogeneous nature of the farming systems are good promoters of innovations and enable French agriculture to adapt to new challenges. The Networks not only enable the observation of these evolutions, but they also act as their catalyst and guide, and help disseminate them.

- How to cite this article: Jousseins C., Fagon J., Belvèze J., Servière G., 2015. Livestock Farm Networks, a system at the center of French farming development. Rev. Elev. Med. Vet. Pays Trop., 68 (2-3): 107-113
- HISTORY AND TERRITORIAL ORGANIZATION OF AGRICULTURAL DEVELOPMENT IN FRANCE

As early as the 1950s, the organization of agricultural development and advice in France (training, advice, experimentation, dissemination) adopted a very strong collective dimension. Since the 1960s, this organization has been at the interface between public policies and proximity relationships (Compagnone et al., 2009). Relations between the State and the farming profession eventually led to the co-management of agricultural development (1966). Over time the organization of advice inherited from the period of farm modernization and production growth was able to adapt in its methods and intervention themes. It became less prescriptive, and adviser-farmer 
relations became more collaborative. Multidisciplinary expertise was strengthened. The group approach to create a local climate favorable to innovation and to set up projects in common was encouraged even if the demand for more personalized individual advice persisted.

The development structures guiding and advising livestock farmers in their projects were established according to a territorial network based on the administrative departments. Departmental chambers of agriculture, the elected institutional representation of the farming profession and many people active in the rural world, have regularly seen their roles become reinforced. They give direction and leadership to actions of support and guidance as well as advice to farmers for the dissemination of technical and economic innovations in livestock farming. Cooperation and economic organizations are also prescribers of technical and sectorial advice.

The technical institutes carry out functions of applied research, expertise, engineering, training and technical coordination for their sector (the French Livestock Institute for herbivore farming, Arvalis for plant production). Public research organizations, such as the National Institute for Agronomic Research (INRA) are positioned upstream of this system to establish the basic knowledge.

\section{COVERING THE DIVERSITY OF MAJOR LIVESTOCK FARMING REGIONS}

In Europe, France ranks among the first three countries for the number of ruminants as it has the leading cattle herd ( 19 out of 89 million head), it is sixth for the number of sheep ( 8 out of 91 million head), and third for goats (1.3 out of 11 million head) (Eurostat 2008 data). The development of livestock farming associated with agronomic potentialities and climatic constraints has led to a differentiation of production areas. These areas tend toward either dairy or meat, but they are not strictly specialized or limited to regional boundaries.

Faced with this mosaic of geographical, soil, climate and farming specialization, French administrative regions or the simple plain/ mountain dichotomy cannot represent this diversity. The French Livestock Institute has devised zoning to present French livestock, understand its functioning strategies and evaluate the impact of political measures at different scales. It also encourages dialog at regional, national or European levels (Pfimlin et al., 2005). Five criteria were selected to classify the areas (Rouquette and Pfimlin, 1995):

- The soil and climate environment with a combination of climate, soil and relief type parameters;

- The physical structure of the farms (e.g. size, field pattern, possible mechanization or not) defining local production and working conditions, including sometimes the local, economic and social history;

- The potentialities for forage crops which influence the choice of animal production (e.g. maize silage possible or not);

- Local demography and land pressure;

- The dynamics of local organizations of production and enhanced value (Protected Designation of Origin, Traditional Specialty Guaranteed).

From these criteria, eight major agricultural regions have been described, of which seven are very important to livestock farming, i.e. the regions of mixed crop-livestock farming, forage farming, intensive farming, grasslands in the North-West, the Center and the East, pastoral farming, wet mountains, and finally high mountains (Figure 1).

This zoning, defined for France and applied to the European agricultural area (with a few adaptations), shows that three of the major areas described (mountains, grasslands and pastoral) represent $60 \%$ of European farms that rear herbivores (Pfimlin et al., 2005). With mainly dairy farming in the North, France is very close to the countries of Northern Europe. As meat and small ruminants prevail in the South, France has points in common with its Mediterranean partners. And as about a quarter of its surface area are mountains, France has the same preoccupations as those of countries in the Alpine Arc.

\section{- LIVESTOCK FARM NETWORKS, A GLOBAL AND TERRITORIAL APPROACH TO LIVESTOCK FARMING}

\section{The result of a long history}

The idea of building development projects devised collectively and organized as a partnership has been supported by the State and leading farming professionals since the $1960 \mathrm{~s}$. As recalled by Cochard (1974), everything that deals with technical progress and its diffusion must restrict itself to the golden rule of a pragmatism founded on the knowledge of what is real. The idea then emerged of a network permanently collecting global and analytical references both in large numbers and in real size, at a level where it is certain that real problems will have to be faced, i.e. at farm level. There were already some examples of networks in Great Britain: "Low Cost Production" (dairy systems) and the "Meat and Livestock Commission". In France, many grassroots players had already been working together (chambers of agriculture, farm management centers, and technical institutes). Their partnership had to be encouraged by structuring missions and expectations.

Tried out for some animal sectors and a few French regions by the French Livestock Institute, these monitoring systems took their inspiration from the experience of local development groups in which a group leader and several farmers held discussions about their practices and gave collective thought to solutions adapted to their

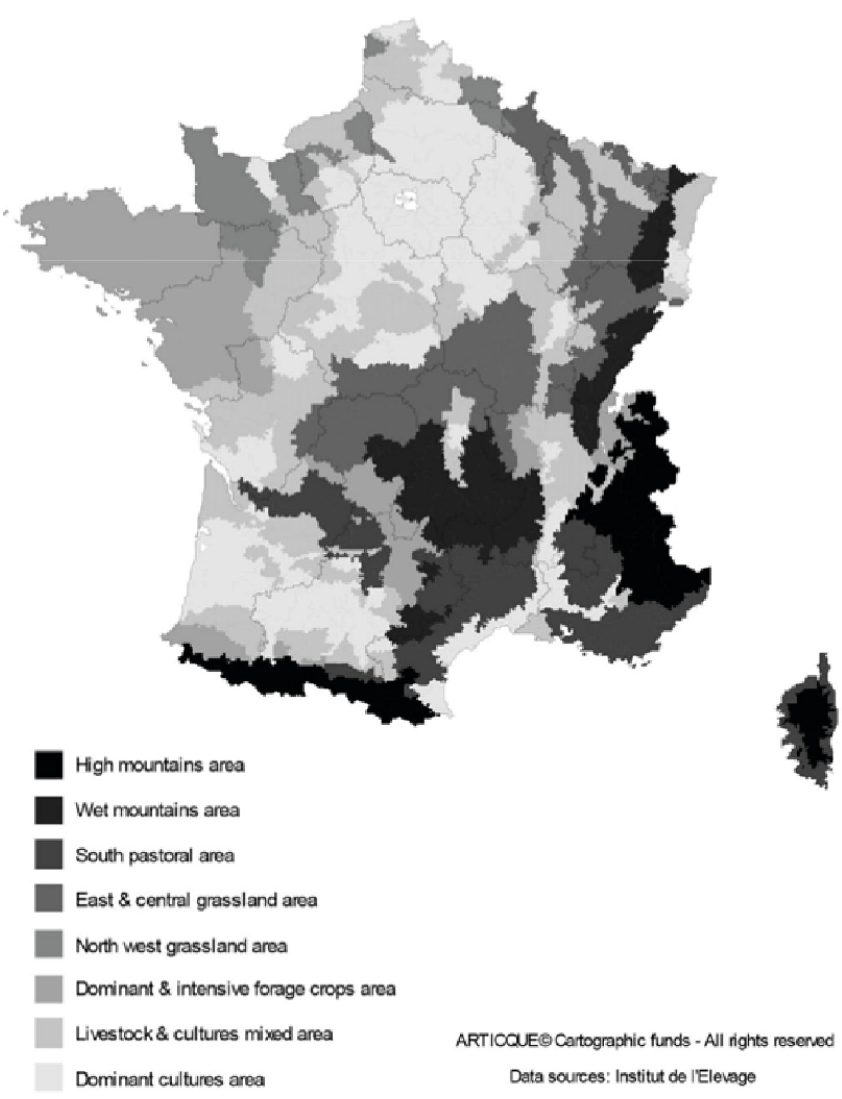

Figure 1: Location of herbivore farming areas (source: French Livestock Institute). 
situation. There was a dimension of territorial development in these groups, but there was not very much dialog or transfer of information between the groups or beyond these groups (Compagnone et al., 2009).

With a foresight network created in 1981, regional and departmental engineers monitored efficient and/or innovative and original livestock farms to construct technical and economic benchmarks adapted to regional contexts and transfer these markers to as many people as possible, in order to suggest paths for the future (infancy of the concept of sustainable development). The analysis method was refined (Lebrun, 1991), and monitoring, collecting and centralizing tools were set up (Diapason software). At the present time, this system appears to be original at international level because few similar organizations have been found in our bibliographical research, even though equivalent systems are in place in a few countries (e.g. Parana State in Brazil, Vietnam).

\section{Missions and objectives of Livestock Farm Networks}

The system territorial organization and the productions which result from this work are coherent with the zoning previously described. It was given the following three missions: i) observe the livestock farming systems in place in the regions, ii) identify and support innovative systems, and iii) transfer and disseminate the productions in the form of tools, methods, training and publications. To do this, the system is organized so as to describe farm functioning in the form of global references, expressing various possible balances in a defined local context. The detailed and regular monitoring of farms over several years also makes it possible to describe farm evolution patterns and paths of evolution which lead to new balances.

\section{The global and systemic approach, the trademark of Livestock Farm Networks monitoring}

The interactions between the biotechnical and human dimensions define the livestock farming system (Dedieu et al., 2008). This systemic vision translates the coherence between herd management and land management, between agronomy and environment, between economic choices and technical choices, between farmer projects and the means to be implemented to achieve them. Communication with the farmers, presenting many viable production systems from the viewpoint of workloads and economic results and accurately describing coherent operational sequences integrating all the units and production systems, are essential parts of the system missions (Delaveau et al., 1999).

Figure 2 shows the livestock farming system concept. The resources mobilized in a livestock farm are described in detail in the main

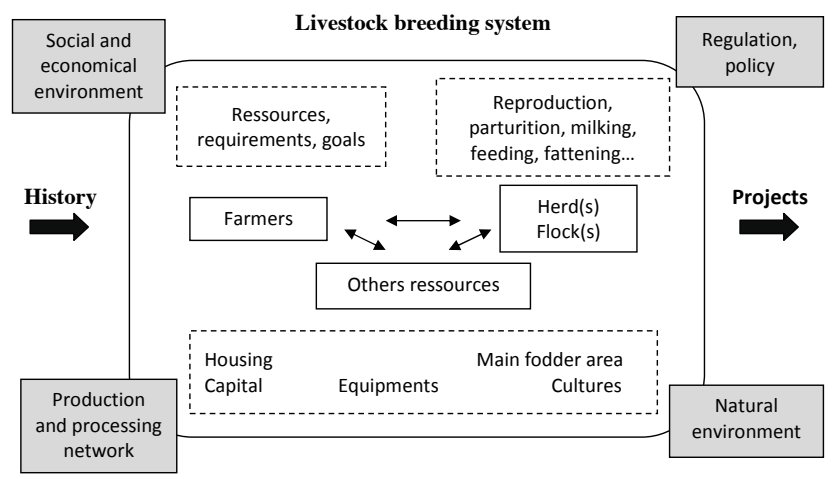

Figure 2: Representation of a livestock farming system and its components (source: French Livestock Institute). framework and are the basis of the information to be collected in the system. The farm evolution pattern is also studied by monitoring the livestock farms and their evolution over several years. These farms are positioned in a variable social, political, economic and environmental context. Taking these variations into account questions all of the players in agricultural development and determines the direction taken by the work and publications carried out by the system.

\section{A SYSTEM WHICH REQUIRES METHOD AND COORDINATION}

\section{Financial support of the Networks}

To be coherent and effective, this system mobilizes many players over several years and requires considerable support, guidance work and farm monitoring. The public administrative establishment, FranceAgriMer, is a major contributor of the Livestock Farm Networks system. Public funds as well as professional farming funds thus finance this system. The financial budget corresponds to five days of work per farm, $50 \%$ financed by FranceAgriMer and $50 \%$ financed by each structure.

\section{Operational functioning of the system}

Such a system involving so many partners requires a lot of coordination to carry out the entrusted missions. The partnership functions very closely between the French Livestock Institute and the 86 departmental bodies. The French organization of agricultural development described earlier makes it easier to set up such an organization because organizations and consultation authorities are already used to working together. Another key point, agricultural development plans are identical regardless of the region. The system thus illustrates the diversity of the systems in France but does not aim at an exhaustive representation of French livestock farms.

The monitoring provides fine knowledge of the functioning and coherence of each livestock farming system. The choice of the systems is made in conformity with the objectives sought by the system and by monitoring the zoning previously presented. Figure 3 and Table I provide information on the farms studied per administrative department and per sector.

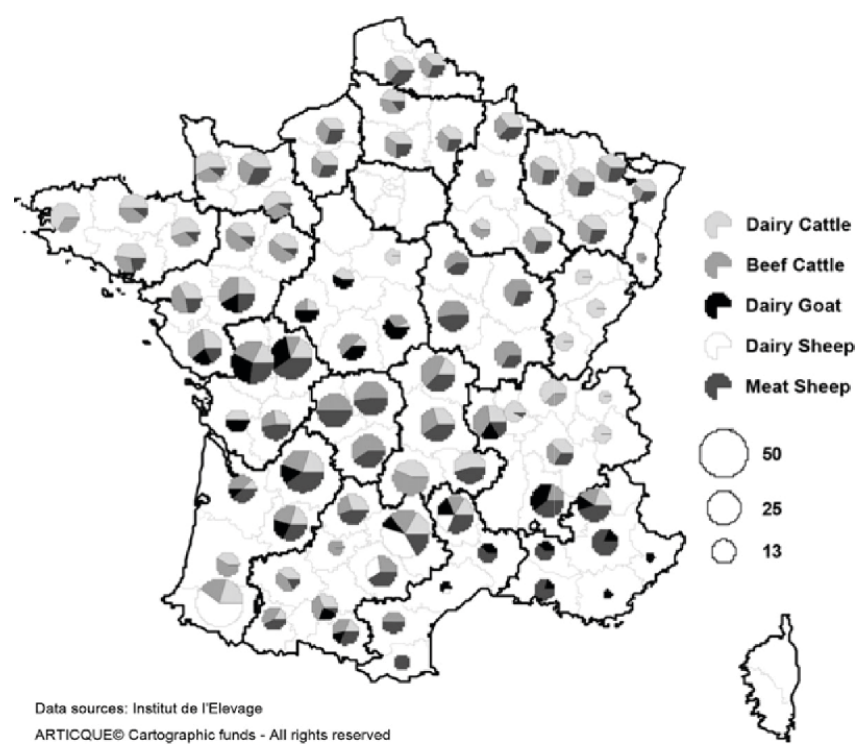

Figure 3: Number of livestock farms monitored per administrative department and per sector in the Livestock Farm Networks (source: French Livestock Institute). 


\section{A regional organization relying on manpower}

The system is regionally organized and based on the trio made of the regional organizer, the grassroots technician and the livestock farmer (Table II). The regional organizer coordinates the actions, fixes the methodological framework and provides the monitoring tools. The technician of a chamber of agriculture makes regular visits to the farms at key periods of the year to understand how the farms function (farmers' objectives, past evolutions, projects) and to collect the information necessary to describe the livestock farming system (workforce, production means, technical results, economic results and environmental impacts). The technicianlivestock farmer pair functions in an approach of reciprocal dialog. The technician collects information and reproduces it in the form of diagnoses and advice to the farmers (progress approach), who can ask for a study of projects to improve or change their farm. The technicians are more often specialized by sector than by this benchmark activity. They rely if necessary on other technicians with complementary skills (feed, buildings, reproduction) (Dockès et al., 2010).

The regional teams meet regularly to harmonize the collection of data and process the information. The data collected are stored in a national database (Diapason) managed by the French Livestock Institute (Charroin et al., 2005). Nationwide discussions between regional organizers ensure that the work is harmonized and organized all across the country (e.g. surveys).

\section{Products and achievements of the system}

Regional and national productions come in the shape of technical and economic benchmarks presented per system (e.g. specialized sheep in the Massif Central, mixed crop-livestock farmers in the plains of the South-West), syntheses of theme studies (e.g. energy in livestock farming, mechanization) and results of annual surveys or of methods and tools. New themes have gradually been included in the monitoring (e.g. mineral balance, energy, production cost).

The comparison of several farms very near each other makes it possible to describe and build coherent, efficient models of farms observable in the field called "farm typologies". These virtual but functional farms are useful for advisers to simulate farmers' projects and distribute functional markers. Politicians can also use them to study the impact of change in support policies (see below).

\section{Uses and users, individuals and collectives}

Monitoring makes it possible to identify, describe and build coherent, efficient production systems adapted to local potentialities and constraints and that the farmers can implement on their farms. As strategic decision-making tools in the individual framework of a farmer-adviser relationship, these technical, economic and thematic methods, benchmarks and markers enable livestock farming advisers to make diagnoses and guide the farmers in their projects (e.g. development of new units, technical reorientation, installation). All these productions and studies make it possible to provide the training and expertise of a body of livestock farming advisers.

The use of these analyses and simulation tools by local or national decision makers improves their knowledge of the production systems present in the entire country (Delaveau et al., 1999). They can test and measure the incidence of new agricultural policies on the different systems in place (Common Agricultural Policy, i.e. reforms influencing the construction of forage systems, influencing support to mountain systems) and thus orientate the final decisions and application methods.

Table I

Monitored French farms

$\begin{array}{lcrr}\text { Animal sectors } & \begin{array}{c}\text { Num. farms monitored } \\ \text { in the Networks }\end{array} & \text { Including mixed systems } & \begin{array}{c}\text { Num. professional } \\ \text { farms* in 2007 }\end{array} \\ \text { Beef cattle } & 450 & \text { Beef and dairy cattle } & 100,200 \\ \text { Dairy cattle } & 400 & \text { Meat sheep and beef cattle; meat sheep and dairy cattle } & 90,100 \\ \text { Meat sheep } & 380 & \text { Dairy sheep and beef cattle; dairy and meat sheep } & 29,200 \\ \text { Dairy sheep } & 60 & \text { Goat and beef cattle; goat and dairy cattle } & 4,800 \\ \text { Dairy goat } & 130 & & 10,400 \\ \text { Total } & 1,420 & & 234,700\end{array}$

Source: Agreste survey structure 2007, Metropolitan France; French Livestock Institute, Livestock Farm Networks

* The professional farm satisfies two conditions: its economic dimension is greater than the equivalent of 12 hectares of corn; the quantity of work applied to it is at least equal to 0.75 annual work unit (definition of professional farms by Agreste, Eurostat).

\section{Table II}

The human means of the French national system

\begin{tabular}{lcc}
$\begin{array}{l}\text { Livestock farms monitored nationally (all } \\
\text { sectors) }\end{array}$ & $\begin{array}{c}\text { Agents in charge of monitoring } \\
\text { (chambers of agriculture, other bodies) }\end{array}$ & $\begin{array}{c}\text { Project leaders for guidance and use of } \\
\text { the system (French Livestock Institute) }\end{array}$ \\
\hline $1,420+500$ monitored on regional funds & $\begin{array}{c}210 \text {, i.e. on average } 9 \text { farms } \\
\text { monitored / agent }\end{array}$ & $\begin{array}{c}35 \text {, i.e. on average teams of } 6 \text { agents } \\
\text { at regional level }\end{array}$
\end{tabular}

Source: French Livestock Institute, Livestock Farm Networks 
LIVESTOCK FARM NETWORKS MOBILIZED AND REACTIVE ON EMERGING THEMES IN THE LIVESTOCK FARMING SECTOR

Using selected examples, the following section presents individual and collective uses of the Networks. These examples respond to the three pillars of sustainable development, i.e. economic, environmental and social.

\section{Measuring and strengthening the competitiveness of livestock farms}

In a context of global and competitive economy where the market of agricultural raw materials is increasingly volatile, it is essential for the players in the industry to know their production costs. Since 2007, the French Livestock Institute has relied on the technical and economic data of the Networks to propose a national method, compliant with international accounting regulations (International Farm Comparison Network, Agri-Benchmark) and applicable to all herbivore farms. This method made it possible to build benchmarks per production system. It is now a basis for many training schemes for technicians and livestock farmers. In the framework of individual advice, the farmers know their production costs per unit produced (1000 liters of milk, 100 kilograms of meat). By comparing them with the benchmarks, they can identify progress margins.

Through a collective use of production cost calculations, they can share and discuss improvement processes. For elected representatives, observing the areas of production and their differences in competitiveness can help target public support policies at farmers to maintain the activity of farms in less favorable areas.

\section{Preserving the environment and limiting the ecological footprint}

Environmental themes are increasingly evoked in demands from European societies. The environmental impacts of farming, and of livestock farming in particular, are regularly discussed (Le Gall et al., 2009). As a consequence, the Networks have integrated methods for measuring impacts on the environment. In recent years, energy consumption and greenhouse gas (GHG) emissions have been measured in all the farms monitored (Hacala and Le Gall, 2006). The Networks make it possible to take on-farm measurements of these criteria to determine the positioning of the livestock farm models in France (Table III) (Galan et al., 2007). Data use has shown how low-consumption farms function with low GHG emissions.

The French Livestock Institute developed in collaboration with the Agency for the Environment and Energy Control and its partners a tool and a method (DIATERRE) to make diagnoses of energy and GHG in farms. At the beginning of 2011, about 300 advisers were trained. They are now using the diagnostic tool and the technical markers obtained from Networks data (Morin et al., 2010), enabling farmers to qualify their energy consumption and reduce it.

\section{Analyzing and organizing work}

The discrepancy between the time farmers spend working and the time the active population in general spends working only adds to the preoccupations of farmers about the problem of work. Faced with the legitimate demand for free time, the increasingly complex nature of the work and the evolution of collective work, concrete responses must be provided to ensure that the farming profession can continue to attract prospective young farmers (Calland, 2009).

Table III

Description and environmental performances of the main dairy systems in France

\begin{tabular}{|c|c|c|}
\hline & $\begin{array}{c}\text { Systems of forage crops } \\
\text { in West France and in foothills }\end{array}$ & $\begin{array}{l}\text { Systems in wet mountains of } \\
\text { the Massif Central and Franche-Comté }\end{array}$ \\
\hline Number of farms & 43,000 & 16,000 \\
\hline Maize/MFA (\%) & $20-50$ & $0-5$ \\
\hline Dominant type of grassland & Temporary grassland & Permanent grassland \\
\hline LU/ha MFA & $1.4-1.7$ & $0.8-1.0$ \\
\hline Milk produced (L/cow) & $6,500-8,000$ & $6,000-7,000$ \\
\hline Milk (L)/ha MFA & $5,000-9,500$ & $3,000-5,500$ \\
\hline Organic $\mathrm{N}$ pressure (kg/ha spreadable) & $100-110$ & $60-80$ \\
\hline Nitrogen surplus* $\left.{ }^{*} \mathrm{~kg} / \mathrm{ha}\right)$ & 80-100 & $30-50$ \\
\hline Organic $\mathrm{P}$ pressure (kg/ha) & $20-22$ & $13-15$ \\
\hline Phosphorus surplus (kg/ha) & 10 & 10 \\
\hline $\begin{array}{l}\text { Direct and indirect energy consumption } \\
\text { (MJ/1,000 L milk) }\end{array}$ & $2,685-4,296$ & $2,685-5,012$ \\
\hline $\begin{array}{l}\text { Greenhouse gas emissions after integration } \\
\text { of carbon storage on grasslands ( } \mathrm{Eq} \mathrm{CO} / \mathrm{L} \text { milk) }\end{array}$ & $0.8-0.9$ & $0.7-0.8$ \\
\hline Pressure of plant health products (g/ha AA) & $800-1,200$ & 0 \\
\hline Biodiversity equivalent area (ares/1000 L milk) & $18-22$ & $38-42$ \\
\hline
\end{tabular}


The approach to livestock farming work was initiated in the 1990s in the framework of the Networks, which led to the "Work assessment" method in partnership with INRA. This method has been recently applied by other animal technical institutes (pigs and poultry).

Since 2010, new updated national "working time" reference systems, established from surveys carried out in 640 livestock farms which belong for most to the Networks, have been available for seven animal sectors (herbivores and granivores). They are sometimes coupled with more qualitative studies, for example in the dairy cattle sector on essential routine work (Chauvat et al., 2003). Similarly, regional use of these surveys has made it possible to propose markers of working times and annual programming of activities to make work organization easier, as it is the case for meat sheep systems in Auvergne (Servière, 2005).

At the same time, "work" technical support methods and tools have been developed in collaboration with grassroots organizations, making it possible in particular to provide markers for starting up projects, as for example goat farming with the "Conseil Travail Caprin" (Guinamard et al., 2010) or beef cattle farming with Travibov (Sarzeaud and Bisson., 2009).

\section{a RECOGNIZED SYSTEM WHICH MUST CONTINUE TO ADAPT}

Variety of productions and heterogeneity of farms have long been presented as signs of the backwardness of French agriculture. However, production diversification has also regularly been presented as a necessary condition for the adaptation of farms to market constraints (Colson, 1986). French livestock farms continue to follow two development strategies: specialization or diversification. Regardless of their orientations, the Networks make it possible to study the strengths and weaknesses of these systems, and describe coherent livestock farms, with appropriate choices in the face of present-day issues. This diversity at territory or farm scale, emphasized by the systemic approach, is not seen as a handicap but as a source of system flexibility and adaptation of French agriculture (Dedieu and Ingrand, 2010).

The Networks provide markers, formalize and give guidance to farmers with regard to new themes initiated by the farmers themselves or by technical institutes, agricultural development bodies, society, the market and current policies. The capacity to anticipate is part of the reactivity of the Networks.

Identifying and studying all the technical innovations implemented in livestock farming is not always obvious, all the more as the system, although representative of existing systems, is not exhaustive and compels to make choices. On the other hand, experimenting new approaches (Life Cycle Analysis for example) on well known farms is easier. Sometimes there is still the difficulty of transmitting these new developments to as many people as possible beyond the farms monitored. Dissemination of knowledge and innovation is however one of the system missions. It is made easier when the economic or political context pressurizes the surroundings of the livestock farm to look into it or when complementary projects are set up.

By relying on a strong partnership between a national technical institute for applied research and local development organizations established all over the country, this system has built up its institutional legitimacy and has been able to use the skills and specificity of each organization to make it such a valuable resource. This is strengthened by the women and the men who make up the Networks. The skills in the teams are varied and often complementary (multidisciplinary approach of the advice). The expertise of all these players also makes it possible to have qualitative elements on the farms and the territory that cannot be proposed by databases.

This system is recognized and supported by farming professionals and public authorities. Its financing is regularly discussed but, and this is a sign of its significance, several farming sectors want such systems to be extended to their own production. As another element of recognition via the Programme of Options Specifically Relating to Remoteness and Insularity (POSEI), Europe supports the setting up of these Networks in more distant territories (New Caledonia, West Indies, French Guyana, La Réunion).

This system requires discussions, agreements and steering authorities. The governance method to be implemented is at times complex to manage as it is composed of numerous partners with sometimes diverging objectives which then call for compromises.

A recurrent criticism of the Networks is that their dimension and multipartnership organization can hinder their reactivity. And yet it is this system that the professional steering committees turn to with questions in the news, for example via complementary theme investigations.

Satisfying their primary function of forming links between players, the Networks are supports for many multipartnership projects of French and European research, development and innovation, with several partner countries; they also participate in international think tanks (International Farm Comparison Network, Agri-Benchmark).

\section{REFERENCES}

Auricoste C., Compagnone C., Lémery B., 2009. Conseil et développement en agriculture: Quelles nouvelles pratiques? Quae, France, www.quae. com/fr/index.html

Calland B., 2009. Le travail dans la formation initiale et continue des futurs agriculteurs. In : $3^{\text {es }}$ rencontres nationales travail en élevage des acteurs du développement, de la recherche et de la formation, Rennes, France, nov. 2009, p. $19-20$

Charroin T., Palazon R., Madeline Y., Guillaumin A., Tchakerian E., 2005. Le système d'information des Réseaux d'élevage français sur l'approche globale de l'exploitation. Intérêt et enjeux dans une perspective de prise en compte de la durabilité. In : $12^{\text {es }}$ Rencontres Recherches Ruminants, Paris, France, 7-8 déc. 2005

Chauvat S., Seegers J., N'Guyen B., 2003. Le travail d'astreinte en élevage bovin laitier - Etat des lieux national élaboré à partir d'une synthèse d'enquêtes Bilan Travail et à travers l'expression des éleveurs du dispositif des Réseaux d'élevage bovin lait. Institut de I'Elevage, Paris, France, www.inst-elevage.asso.fr/spip.php?article1437

Cochard J., 1974. Réflexions sur la recherche et le développement. Econ. Rurale, 99 : 15-21

Colson F., 1986. Le développement agricole face à la diversité de I'agriculture française, Econ. Rurale, $172: 3-9$

Dedieu B., Faverdin P., Dourmad J.-Y., Gibon A., 2008. Système d'élevage, un concept pour raisonner les transformations de l'élevage. INRA Prod. Anim., 21 (1) : 45-58

Dedieu B., Ingrand S., 2010. Incertitude et adaptation : cadres théoriques et application à l'analyse de la dynamique des systèmes d'élevage. INRA Prod. Anim., 23 (1) : 81-90

Delaveau A., Perrot C., Beguin E., Léger F., 1999. Les Réseaux d'élevage pour le conseil et la prospective. CIHEAM-IAMZ, Saragosse, Espagne, p. $99-103$

Dockès A.-C., Couzy C., Kling-Eveillard F., Frappat B., Chauvat S., Fourdin S., Godefroy C., Mille S., Parguel P., Rubin B., Servière G., Madeline Y., 2010. Prendre en compte la diversité des points de vue des éleveurs et intervenants de terrain pour coconstruire des démarches et outils de conseil. L'expérience de I'Institut de I'Elevage. In : Colloque SFER Conseil en agriculture : acteurs, marchés, mutations, Dijon, France, 14-15 oct. 2010 
Galan G., Dollé J.-B., Charroin T., Ferrand M., Hiet C., 2007. Consommation d'énergie en élevage bovin. Des repères pour se situer et progresser. In : $14^{\mathrm{es}}$ Rencontres Recherches Ruminants, Paris, France, 5-6 déc. 2007

Guinamard C., Chauvat S., Bossis N., Caramelle-Holtz E., 2010. Conseil Travail Caprin. Institut de l'Elevage, Paris, France, http://idele.fr/metiers/ partenariat-r-d/rmt-travail-en-elevage/publication/idelesolr/recommends/ conseil-travail-caprin.html

Hacala S., Le Gall A., 2006. Evaluation des émissions de gaz à effet de serre en élevage bovin et perspectives d'atténuation. Fourrages, 186 : 215-227

Lebrun V., 1991. Une méthode d'étude du système d'exploitation agricole, $2^{\mathrm{e}}$ édn. ITEB, Paris, France, 63 p.

Le Gall A., Beguin E., Dollé J.-B., Manneville V., Pflimlin A., 2009. Nouveaux compromis techniques pour concilier efficacité économique et environnementale en élevage herbivore. Fourrages, 198 : 131-151
Morin C., Beguin E., Belvèze J., Bossis N., Capdeville J., Chambaut H., Charroin T., Corbet V., Dollé J.-B., Jousseins C., Leclerc M.-C., Manneville V., Martineau C., Morin E., 2010. Consommation d'énergie en élevages herbivores et leviers d'action. Institut de l'Elevage, Paris, France (Coll. méthodes et outils)

Pfimlin A., Buczinski B., Perrot C., 2005. Proposition de zonage pour préserver la diversité des systèmes d'élevage et des territoires européens. Fourrages, $182: 311-329$

Rouquette J.-L., Pfimlin A., 1995. Les grandes régions d'élevage : proposition de zonage pour la France. In : $4^{\mathrm{e}}$ symp. int. Nutrition des herbivores, Clermont-Ferrand, France, 11-15 sept. 1995

Sarzeaud P., Bisson P., 2009. TRAVIBOV - aide à I'amélioration du travail en élevage bovin viande. In : $3^{\text {es }}$ Rencontres nationales travail en élevage des acteurs du développement, de la recherche et de la formation, Rennes, France, 19-20 nov. 2009

Servière G., 2005. En Auvergne, un système ovin herbager avec un couple. Institut de I'Elevage, Paris, France http://idele.fr/fileadmin/medias/ Documents/OS_Auvergne_herbager_couple_1000_brebis_V1.pdf

\section{Résumé}

Jousseins C., Fagon J., Belvèze J., Servière G. Les Réseaux d'élevage, un système au centre de l'évolution de l'élevage en France

Les Réseaux d'élevage sont un dispositif dédié au développement de l'élevage herbivore. Fruit de I'histoire du développement agricole français, ils sont présents sur l'ensemble du territoire national et s'organisent localement. L'originalité de ce dispositif provient de sa nature partenariale entre des éleveurs, les chambres d'agriculture et l'Institut de l'élevage, de sa prise en compte de la diversité des régions d'élevage et de l'étude des systèmes d'élevage à travers l'approche globale. L'objectif n'est pas d'être exhaustif mais d'être représentatif de l'élevage herbivore à travers le choix des systèmes étudiés, d'en mesurer les évolutions, de créer et de diffuser des références à partir du suivi de 1900 fermes réalisé par 210 agents des chambres d'agriculture, encadré par 35 animateurs de l'Institut de l'élevage, et financé et appuyé par les pouvoirs publics et la profession agricole. Les valorisations régionales et nationales des Réseaux s'adressent à différents publics : aux éleveurs, aux conseillers, aux enseignants (pour le conseil ou la formation), aux individus ou aux collectifs, et aux décideurs locaux et nationaux afin de mieux comprendre les systèmes d'élevage, et de mesurer l'impact de nouvelles politiques agricoles et d'orienter leur modalité d'application. Le rôle des Réseaux s'illustre également dans leur capacité à se mobiliser sur des thématiques émergentes. Les aspects viabilité, compétitivité, conditions de travail ou encore enjeux environnementaux étaient inclus dans les champs d'étude du dispositif bien avant que le concept de développement durable ne devienne un centre d'intérêt. Les Réseaux en tant que dispositif partenarial sont parfois complexes à gérer et paraissent coûteux, mais $c^{\prime}$ est ce partenariat fort qui leur apporte la reconnaissance en tant que ressource clé et qui leur donne leur légitimité. La diversité des productions agricoles et l'hétérogénéité des systèmes d'exploitation favorisent les innovations et permettent I'adaptation de l'agriculture française aux nouveaux enjeux. Les Réseaux d'élevage permettent non seulement d'observer ces évolutions mais également de les catalyser, de les accompagner et de les diffuser.

Mots-clés : système d'exploitation agricole, système d'élevage, conduite d'élevage, élaboration de systèmes, développement agricole, conseiller agricole, agriculture durable, France

\section{Resumen}

Jousseins C., Fagon J., Belvèze J., Servière G. Redes de Fincas Ganaderas, un sistema en el centro del desarrollo finquero francés

El sistema de Redes de Fincas Ganaderas se dedica al desarrollo de la producción de herbívoros. Debido a que las Redes son el resultado histórico del desarrollo agrícola francés, se encuentran en toda Francia y están organizados a nivel local. La originalidad del sistema reposa en el asociación entre finqueros, cámaras de agricultura y el Instituto Francés de Ganadería y por ende utiliza un enfoque global que considera la diversidad de las regiones de fincas ganaderas y el estudio de sistemas de fincas ganaderas. A pesar de no ser exhaustivos, los sistemas estudiados representan los sistemas de fincas de herbívoros. Se evalúa su evolución y se crean y distribuyen puntos de referencia. Estos puntos de referencia se han establecido según el monitoreo de 1900 fincas, por parte de 210 agentes de cámaras de agricultura, guiados por 35 líderes de proyecto pertenecientes al Instituto Francés de Ganadería, y financiado y sostenido por las autoridades públicas y las entidades de profesionales de agricultura. La progresión regional y nacional de las Redes, se dirige a audiencias diversas: finqueros, consejeros, educadores (para consejo o entrenamiento), individuos o colectividades, y líderes a nivel nacional o local con el fin de mejorar la comprensión de los sistemas de fincas ganaderas, así como para medir el impacto de nuevas políticas de producción y guiar su implementación. Mostramos también la capacidad de las Redes para movilizarse en temas emergentes. Sostenibilidad, competitividad, condiciones de trabajo e incluso temas ambientales han sido cubiertos por los campos de estudio del sistema, bastante antes de que el desarrollo sostenible se convirtiera en un tópico a la moda. Las Redes, en tanto que sistema de asociación, puede ser algunas veces complejo de manejar y puede parecer costoso, pero una asociación fuerte y bien reconocida la ha transformado en un recurso valioso y ha asegurado su reconocimiento y legitimación. La variedad de los sistemas de producción y la naturaleza heterogénea de los sistemas de producción son buenos promotores de innovaciones y permiten a la agricultura francesa la adaptación a nuevos retos. Las Redes no sólo permiten la observación de estas evoluciones, sino que actúan como catalizador y guía y ayudan a la diseminación.

Palabras clave: sistema de explotación, sistemas de cría, manejo del ganado, creación de un sistema de organización, desarrollo agrícola, agente de extensión, agricultura sostenible, Francia 
